\title{
THE STUDY OF MODERN APPROACHES TO PROVISION OF PHARMACEUTICAL CARE IN THE CONDITIONS OF GOOD PHARMACY PRACTICE INTRODUCTION
}

\author{
V.M.Nazarkina, O.A.Nemchenko \\ National University of Pharmacy \\ Key words: pharmaceutical care; pharmaceutical service; pharmacy practice; pharmacotherapy; \\ system (comprehensive) approach
}

\begin{abstract}
It has been shown that nowadays pharmaceutical provision of the population is a complex integration system that combines pharmaceutical care, pharmaceutical services, the process of drug supply and professional pharmacy practice. The content of such concepts as pharmaceutical care and pharmaceutical service, as well as medication therapy management have been determined. Two approaches to the management of pharmaceutical services in the process of changing the vector of the professional activity of a pharmacist have been reviewed. With regard to the implementation of such services there are two approaches: a focus on a product (drug) and focus on a patient. The basic functional differences between these two approaches in providing pharmaceutical services have been identified. A comparative analysis of the parameters for such concepts as pharmaceutical and medical care has been carried out. It has been shown that the process of medication therapy management includes three levels: system (public policy, regulation and legislation), institutional (control lists, formularies and protocols) and individual (pharmaceutical care). From positions of the system approach the process of pharmaceutical care by the patient's treatment planning has been considered.
\end{abstract}

In 1998 FIP was first adopted the "Regulations on professional standards of pharmaceutical care". It offers guidance for national healthcare systems (NHS) regarding implementation of pharmaceutical care. The new paradigm of good pharmacy practice (GPP) is presented in the joint publication of the WHO and FIP "Developing pharmacy practice. A focus on patient care". In 2011 FIP jointly with the WHO adopted an updated version of good pharmacy practice "Joint FIP/WHO guide to good pharmacy practice: standards of pharmacy services quality" $[1,2,4]$.

There is a tendency in the world to shift the focus of a pharmacist initially focused only on medicines in providing of pharmaceutical care (PC) to a patient. Therefore, the role of the pharmacist has evolved, and he has turned from someone who prepares and sells medicines on the provider of service and information $[1,5]$. The complexity of the evolutionary processes of changing the role of pharmacists in the pharmacy practice makes it particularly relevant to study the approaches for providing PC to patients $[1,7,9]$.

\section{Materials and Methods}

The analysis of domestic and foreign sources has revealed that at present there are no analytical system studies of peculiarities for providing PC to the patients in pharmacies $[2-6,10]$. In this context, the aim of the study was a systematic analysis of approaches of providing PC to patients in the pharmacy practice. The objects of the study were scientific concepts and terms directly related to the PC provision and professional practice.

Results and Discussion

Pharmaceutical service involves all kinds of services provided by pharmacists in the framework of PC. To- gether with dispensing drugs such services also include informing, education and counseling. Pharmaceutical service is PC given to the population as a result of the pharmacist professional practice that have cost estimate (based on contractual prices).

Analysis of the modern approaches to the PC provision needs to consider the concept of pharmaceutical service associated with the English term "medication therapy management". This term was introduced in the USA in connection with the activities of the federal health insurance programme Medicare for seniors (2006). The term "medication therapy management" is defined as professional activities, in which the help is given to a patient according to the certain standards that ensure each patient to use drugs individually corresponding to the medical case and have an effective and safe therapy using the system (comprehensive) approach [5].

The term "system" is characteristic of the American approach and means the provision of medical and pharmaceutical care to patients in order to achieve the necessary results of individual therapy and coordinate medical and pharmaceutical professionals. This change of the professional activities vector is related with the existence of two approaches for the so-called pharmaceutical service management. From the point of view of implementation of such services, there are two approaches: focus on a product (drug) and focus on a patient $[4,10,11]$. The main differences of both approaches are shown in Fig. 1.

The first of these approaches is traditional for many countries and is associated with the process of drug 


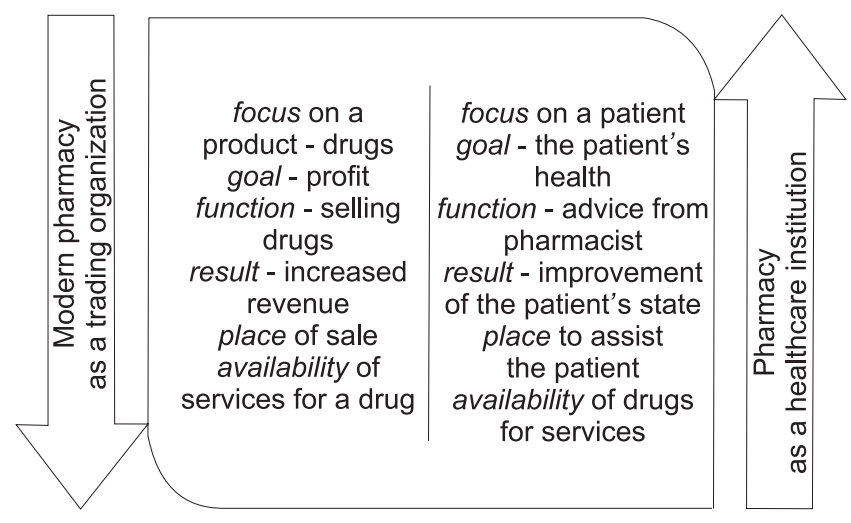

Fig. 1. The main functional differences between two approaches in providing pharmaceutical services.

distribution from the manufacturer to the patient, i.e. the pharmacy performs its commercial function in order to obtain the maximum profit. The focus is clearly aimed at selling the product with occurrence of many economic and ethical conflicts of interests that lead to many negative effects, such as polypragmasy. Usually a patient in this approach is not at the first place, and the problem of appropriate drug therapy and pharmacy practice is inferior to business interests.

The second approach separates the process of providing pharmaceutical services from the process of drug sales and determines it as a resource to achieve the ultimate goal. As part of this approach the activity of the professionally trained specialist such as a clinical pharmacist in hospitals or outpatient services or a pharmacist in an ordinary pharmacy giving consultations is considered. Pharmaceutical services are based on professional PC practice, which provides individual level of service, and is regarded as one of the types of care within the concept of a self-care patient. A pharmacist within PC is responsible for decisions concerning the results of therapy that should be effective and safe. This leads to the conclusion that such a service is an independent process and does not replace the role of doctors.

Medication therapy management involves three levels: system (public policy, regulation and legislation), institutional (regulatory lists, formularies and reports) and individual level. PC can be directed both to individuals and to groups of the population.

Within the "PD-oriented to the population" in order to create formularies or lists of drugs one can use demographic and epidemiological data, develop the regulatory framework for the pharmaceutical sector and monitor its practical introduction, create and manage pharmacy networks, prepare and analyze reports as for drug administration, evaluate the use of drugs and inform health professionals about standards and algorithms for the activities of pharmaceutical institutions.

Without individual PC no healthcare system is able to provide effective drug therapy and the monitoring of its results arising from the use of drugs. These measures implemented at the population level are carried out before or after the medical examination of the patient and obtaining relevant information from him, but they can not replace pharmaceutical services focused on a patient and provided with direct contact. Patients need the services of a pharmacist at the time of medical care.

Successful pharmacotherapy is individual for each patient. It involves individual approach in decision-making concerning the drug therapy model choice, achieving concurrence (agreed position between a patient and a professional providing care regarding therapeutic outcomes and ways to achieve them), as well as very important measures on monitoring of the patient's condition.

The system approach to providing individual PC to a patient is shown in Fig. 2. For individual treatment of each individual patient a pharmacist develops a treatment plan with him/her.

Therefore, patients can make their contribution to the success of therapeutic results taking a share of responsibility for their own treatment and not resting it entirely on healthcare professionals as it was done previously within the paternal approach.

The results of comparison of the parameters of the concepts of medical and pharmaceutical care are given in Table.

In this context, the role of the pharmacist in the healthcare system is fundamentally changing. Practice of PC is new and significantly different from what was the activity of pharmacists in recent years. Thus, the cor-

Stage 1

Assessment of the needs and identification of the pharmacotherapy problems

Stage 2

Development of the care plan

Stage 3

Implementation of the care plan

Stage 4

Monitoring and review of the care plan

Fig. 2. The system approach to providing pharmaceutical care to a patient. 
A comparative analysis of parameters of medical and pharmaceutical care

\begin{tabular}{|l|l|l|l|}
\hline The type of care & \multicolumn{1}{|c|}{ Primary focus } & Basic knowledge & \multicolumn{1}{|c|}{ A decision on using a drug } \\
\hline Medical & $\begin{array}{l}\text { Diagnosis and treatment } \\
\text { of a patient }\end{array}$ & Pathophysiology & Prescribing the drug \\
\hline Pharmaceutical & $\begin{array}{l}\text { Identification and satisfaction of } \\
\text { the patient's needs in medications }\end{array}$ & Pharmacotherapy & $\begin{array}{l}\text { Prevention and solution of problems } \\
\text { associated with pharmacotherapy }\end{array}$ \\
\hline
\end{tabular}

nerstone in modern practice of PC providing is a professional responsibility of a pharmacist.

CONCLUSIONS

The study of approaches for providing PC and their scientific generalization are important and relevant for development of good pharmacy practice in Ukraine. Modern PC should be considered as pharmacy practice that involves the professional responsibility of a pharmacist for implementation of pharmaceutical services with the focus on a patient.

\section{REFERENCES}

1. Дремова Н.Б., Коржавых Э.А., Литвинова Т.М. и др. // Фармация. - 2005. - №2. - С. 37-45.

2. Належна аптечна практика. Стандарти якості аптечних послуг: Спільна настанова МФФ/ВООЗ від 01.01.2011 p. Режим доступу до настанови: http://zakon2.rada.gov.ua/laws/show/897_009.

3. Панфілова Г.Л., Немченко А.С., Немченко О.А. Організачія фармацевтичної допомоги населенню в умовах медичного страхування. - Х.: Ависта-ВЛТ, 2009. - 226 с.

4. Розвиток фармачевтичної практики: фокус на пацієнта. Настанова BООЗ, 2006 (Developing pharmacy practice - A focus on patient care. WHO Guideline, 2006). - 65 c.

5. Bluml B. // J. Am. Pharm. Assoc. - 2005. - Vol. 45. - P. 566-572.

6. Cousins D., Kijlstra N., Walser S. Pharmaceutical Care: Policies and Practices for a Safer, More Responsible and Cost-effective Health System. - Strasbourg: EDQM, 2012. - 62 p.

7. Hepler C.D., Strand L.M. // Am. J. Hosp. Pharm. - 1990. - Vol. 47. - P. 533-43.

8. Medication therapy management in pharmacy practice: core elements of an MTM service model (version 2.0) // J. Am. Pharm. Assoc. - 2008. - Vol. 48. - P. 341-353.

9. Rickles N.M., Wertheimer A.I., Smith M.C. Social and Behavioral Aspects of Pharmaceutical Care. 2-nd ed. Boston: Jones \& Bartlett Publishers, 2010. - 484 p.

10. Rovers J.P., Currie J.D. A Practical Guide to Pharmaceutical Care. - Washington: APhA, 2012. - Peжuм docmyny: http://www.pharmacist.com/learning-aids-practical-guide-pharmaceutical-care-3rd-edition.

11. Strand L., Cipolle R., Cipolle R.J. et al. Pharmaceutical Care Practice: The Patient-Centered Approach to Medication Management. 3-rd ed. - New York: McGraw Hill Medical, 2012. - 704 p.

\section{ДОСЛІДЖЕННЯ СУЧАСНИХ ПІДХОДІВ ДО НАДАННЯ ФАРМАЦЕВТИЧНОЇ ДОПОМОГИ В УМОВАХ ВПРОВАДЖЕННЯ НАЛЕЖНОЇ АПТЕЧНОЇ ПРАКТИКИ \\ В.М.Назаркіна, О.А.Немченко \\ Ключові слова: фрармацевтична допомога; фрармацевтична послуга; аптечна практика; фрармакотерапія; системний підхід}

Показано, що на теперішній час фрармацевтичне забезпечення населення є складною інтеграційною системою, яка поєднує фрармацевтичну допомогу, фрармацевтичні послуги, процес забезпечення ліками та професійну аптечну практику. Визначено зміст понять фрармацевтичне обслуговування та фрармацевтична послуга, а також medication therapy management. Розглянуті два підходи до менеджменту фрармацевтичних послуг у процесі зміни вектора профресійної діяльності фрармацевта. 3 точки зору здійснення таких послуг виділяються два підходи: фоккус на товар (Drug) та фрокус на пацієнта. Встановлені основні фрункціональні відмінності обох підходів в наданні фрармацевтичних послуг. Виявлені переваги сучасних фрармацевтичних послуг, орієнтовані на пацієнта: фрармацевт несе відповідальність за результати фрармакотерапії, яка має бути ефрективною та безпечною. Здійснено порівняльний аналіз параметрів понять фрармацевтична та медична допомога. Показано, що процес Medication therapy management передбачає три рівні: системний (державна політика, регулювання та законодавство), інституційний (регулюючі переліки, фрормуляри та протоколи) та індивідуальний (фармацевтична допомога). 3 позицій системного підходу розглянуто процес надання фрармацевтичної допомоги шляхом складання плану лікування пацієнта. 


\section{ИССЛЕДОВАНИЕ СОВРЕМЕННЫХ ПОДХОДОВ К ОКАЗАНИЮ ФАРМАЦЕВТИЧЕСКОЙ ПОМОЩИ В УСЛОВИЯХ ВНЕДРЕНИЯ НАДЛЕЖАЩЕЙ АПТЕЧНОЙ ПРАКТИКИ \\ В.Н.Назаркина, О.А.Немченко \\ Ключевые слова: фрармацевтическая помощь; фрармацевтическая услуга; аптечная} практика; фрармакотерапия; системный подход

Показано, что в настоящее время фрармацевтическое обеспечение населения является сложной интеграционной системой, которая сочетает фармацевтическую помощь, фрармацевтические услуги, процесс обеспечения лекарствами и профессиональную аптечную практику. Определено содержание понятий фрармацевтическое обслуживание и фрармацевтическая услуга, а также medication therapy management. Рассмотрены два подхода к менеджменту фрармацевтических услуг в процессе изменения вектора профрессиональной деятельности фрармацевта. С точки зрения осуществления таких услуг выделяются два подхода: фрокус на товар (Drug) и фокку на пациента. Установлены основные фрункциональные различия обоих подходов в предоставлении фрармацевтических услуг. Выявлены преимущества современных фрармацевтических услуг, ориентированных на пациента: фрармацевт несет ответственность за результаты фрармакотерапии, которая должна быть эфрфективной и безопасной. Осуществлен сравнительный анализ параметров понятий фрармацевтическая и медицинская помощь. Показано, что процесс Medication therapy management предусматривает три уровня: системный (государственная политика, регулирование и законодательство), институциональный (регулирующие перечни, формуляры и протоколы) и индивидуальный (фрармацевтическая помощь). С позиций системного подхода рассмотрен процесс предоставления фрармацевтической помощи путем составления плана лечения пациента. 